\title{
The Effect of Extensive Reading on Iranian EFL Learners' Motivation for Speaking
}

\author{
Ramin Rahmany \\ Islamic Azad University, Takestan Branch, Iran \\ Abbas Ali Zarei \\ Imam Khomeini International University, Qazvin, Iran \\ Sohaila Gilak \\ Islamic Azad University, Takestan Branch, Iran
}

\begin{abstract}
The present study was conducted to investigate the effect of extensive reading (ER) on Iranian EFL learners' motivation for speaking. The participants were 60 students from different levels (i.e., 20 elementary, 20 intermediate and 20 advanced) at an English institute in which there was a library. The participants did ER for twelve weeks ( 2 semesters) and studied three books (graded readers) in one week. To meet the aim of the study, a 155-item questionnaire (Gardner's 104-item AMTB questionnaire (Gardner, 1985) and 51-item questionnaire developed by Schmidt et al., 1996) were administered to the participants. Data were analyzed using ANOVA. Results indicated that ER did not have a significant effect on EFL learners' motivation for speaking across the three levels.
\end{abstract}

Index Terms — extensive reading, motivation, graded readers, speaking

\section{INTRODUCTION}

A number of researchers (Bell, 2001; Day \&Bamford, 1998; Leung, 2002; Nation, 1997; Takase, 2007; Yamashita, 2008) have stressed that Extensive Reading (ER) can play an important role in learners' language education and language proficiency. ER seems to have outstanding effects on improving all four language learning skills (i.e., listening, speaking, reading and writing). Learners benefit from ER in a range of language uses and language knowledge (Shen, 2008). According to Tanaka and Stapleton (2007), and Mason and Krashen (1997), many studies (Bell, 2001; Shue, 2004) have emphasized the benefits of ER and its positive impact on reading comprehension, vocabulary knowledge, writing performance and grammatical competence. Apart from these, ER has been shown to have a considerable effect on foreign language (FL) learners' motivation to read as an effective domain (Leung, 2002; Mason \&Krashen, 1997; Nishino, 2007; Takase, 2007). The emphasis on motivation is essential for weak readers who lack the will to read and find FL learning difficult.

The most widely used concept for explaining the failure or success of FL learners is motivation. As a key factor in following anything in our lives (Gardner, 2001b-as cited in Kato, Yasumoto\& Van Aacken, 2007), motivation also plays an important role in language acquisition. It provides a source of energy that is responsible for why learners decide to make an effort to learn another language and how long they are going to continue it (Brewster \&Fager, 2002).

Reading is a source of information and a pleasant activity which must be learnt because of its importance as a communicative and learning tool. Among all benefits of ER, the two obvious goals are enabling students to read without stopping and providing an increased knowledge of words (Day \&Bamford, 1998). Benettayeb (2010) has stated that ER is a kind of active process which involves the reader in getting the meaning, interpreting and extracting information. It may be a good way for EFL learners who want to keep contact with English outside the classroom with no help. He has also contended that ER mainly zooms on recognizing and solving some reading difficulties related to vocabulary knowledge. Apart from these, EFL learners make noticeable gains on grammar too. Kit U (2009) has claimed that almost all participants (92 of the 99 experimental students) in his study reported the positive effect of ER program on their L2 vocabulary, grammar and reading comprehension. Therefore, when the vocabulary and grammatical knowledge of FL learners increase, they become more interested and motivated in reading (Day \&Bamford, 1998; Jarrell, 2003) and this may lead to a high level of interest in communication.

Students' motivation is an important factor in the success of anything they want to do. In SLA studies, there are two important classifications for motivation: intrinsic/extrinsic and integrative/instrumental. Intrinsic motivation, which is important in promoting success, refers to the motivation inside a person with no reward except the activity itself, while extrinsic motivation refers to the motivation outside a person with an expectation of reward from outside (Brewster \& Fager, 2000; Chalak\&kassaian, 2010; Zubairi\&Sarudin, 2009).

Gardner and Lambert (1972) argued that integrative motivation means the desire to find out about the culture of SL and learn it to communicate with its members to become a part of that society, this is different from instrumental 
motivation that refers to the motivation to acquire SL as a means of promoting a career or job or reading technical texts (as cited in Chalak\&Kassaian, 2010).

As mentioned above, motivation is one of the crucial predictors of FL performance and has a basic role in language acquisition (Mori, 2002). Teachers often observe in their classrooms that students prefer to be silent; they avoid asking and answering questions. This avoidance may be due to lack of enough vocabulary knowledge which affects students' motivation for speaking. Students' unwillingness to speak and communicate in FL classroom will often lead to unwillingness to communicate in real contexts. The question which is raised here is "how can we enhance FL learners' motivation for speaking in both classroom and real contexts?"

\section{RESEARCH QUESTIONS}

The present study aims at answering the following questions:

1. Is there any improvement in FL learners' motivation for speaking following an ER program?

2. Are there any significant differences among the effects of ER on elementary, intermediate and advanced learners' motivation for speaking?

\section{LITERATURE REVIEW}

Mason and Krashen (1997), in their study about university level students of English as a foreign language in Japan who had failed English, proposed that after a semester of doing ER program, the experimental group's gains were greater than the gains made by the comparison group in reading comprehension and reading motivation. In this study the improvement in attitudes and motivation shown by the experimental students was the most important and influential finding which helped unwilling students of EFL to become earnest readers.

Day and Bamford published a book in 1998 in which the characteristics of ER and its positive effects on different language skills were discussed. The authors defined ER as "an approach to the teaching and learning of second language reading in which learners read large quantities of books and other materials that are well within their linguistic competence" (p. 8). They claimed that ER can play an important role in learners' language education and language proficiency. They claimed that the success of ER depends considerably on interesting texts- "in the absence of interesting texts very little is possible" (p. 28). This success can be gained through reading graded readers which provide important factors such as "entertainment, information, learning to read and becoming hooked on books" (p. 61). The findings of their study indicated a large amount of positive results in reading ability, reading motivation, reading speed, word recognition, vocabulary size, grammar, fluency, spelling and automaticity.

Leung (2002) investigated the effect of ER on a Japanese female adult's self-study over a 20 -week period. He gained some outstanding results about that learner in his study. A big improvement was shown in the learner's ability to recognize words and use them in semantically and grammatically correct sentences. Leung claimed that the gains in grammar and vocabulary knowledge resulted from the large linguistic input she experienced through ER and self-study. In addition, her reading comprehension gradually improved and she got this opportunity through ER and self-study as well. Furthermore, both her confidence and her excitement toward reading increased gradually. As a result, her positive attitude towards reading also improved. Leung asserted that having a large quantity of reading materials suited to each learner's interest and their proficiency level, was a key factor in successful ER.

Mori (2002) conducted an investigation into motivation to read in a foreign language. He hypothesized that motivation to communicate and motivation to read may be different and unrelated. A total number of 447 female students of a university participated in this study. The findings indicated that in Japan, where students do not have enough contact with English language and English culture, students do not have the necessary desire to read English newspapers, magazines, etc. It was also revealed that the more L2 learners contact with the target language, the more they become motivated to read in L2. However, their willingness and motivation to read did not affect their motivation to communicate. Consequently, according to the gained results, motivation to read and motivation to communicate can be neither the same nor related.

Asraf and Ahmad (2003) investigated the effect of ER program on reading motivation in three rural secondary or middle schools in Malaysia with the purpose of motivating students to read extensively as much as possible, helping them solve their problems in understanding texts. They discussed the principles of ER for rural school students, the purpose of the reading program and its characteristics, the materials used, and the attitudes of students participating in the program. The results suggested that ER was one of the best ways to help students develop their proficiency in language learning. They also showed that students, who read extensively, learned the language incidentally, their positive attitudes towards reading were increased and finally their language proficiency was improved. This study was done during a period of four months and the findings suggested that rural school students gained some advantages from doing ER. Almost all of the students in this study developed positive attitudes towards reading in English and became motivated to read English books. The findings also revealed that students' language proficiency was also increased through this longitudinal reading program.

The effect of ER on developing FL competence specially on reading comprehension, attitudes towards and motivation for learning FL has been studied in many studies over the past decade. Hitosugi and Day (2004) in their 
study about doing ER program in a Japanese university for beginners gained positive results after a ten-week program which showed that students' scores were enhanced with a traditional measure of reading comprehension. They also found positive and outstanding results in students' attitudes toward and motivation for learning Japanese. In this study, Hitosugi and Day claims that ten weeks is too short to gain remarkable results in language learning. However, the beginner students of the university showed great improvement by reading easy materials.

ER program has been implemented in many educational environments in Japan. Powel (2005) studied the role of this kind of reading in Japanese high schools. The results showed that ER increased learners' reading abilities and other language skills; it was also a basis for listening, speaking and writing activities. Students who participated in this program confirmed that not only they enjoyed ER, but also their abilities and attitudes developed. As students chose books within their own capability range, less proficient students were not worried about not keeping up with advanced ones. In this way their motivation to read improved. Powell also observed a great development in vocabulary and grammatical knowledge, automaticity, comprehension skills, confidence and motivation during his study. Therefore, ER has an important role in language learning process.

Rosszell (2006), in his study about the role of ER in second language vocabulary acquisition, indicated some purposes, such as increasing ER practitioners' awareness of the importance of vocabulary acquisition, and stimulating them to focus on their practices which follow all the suggestions made in the second language vocabulary acquisition literature. He argued against the usefulness of inferring word meanings from context and suggested that although guessing the meaning of the words from context might be useful comprehension strategy and probably a practical way to strengthen known vocabularies, it was a deficient strategy for learning new vocabulary (Hulstijn, 2001; Nation, 2001). In ER, learners read self-selected books and titles with few follow-up activities to fix the gained knowledge, as a result of his experimenting with both self-selected group and class readers, Rosszell found that class reader approach was more practical and suitable for learners' needs. He added that when learners read books as a class, many of their difficulties can be overcome in comparison with readers who read self-selected books. Moreover, teachers can directly observe the problems. He also maintained that as learners work in pairs and in groups; they gain word meaning and usage from each other. Therefore, they comprehend, remember and use new vocabularies better and easier.

Pigada and Schmitt (2006) examined the effect of ER on vocabulary acquisition. This case study of a French learner analyzed the effect of ER on improving lexical knowledge and how vocabulary acquisition changes in relation to how often learners encounter words in the text. The results showed that firstly, ER increased the knowledge of spelling, meaning and grammatical behavior of words in the text. Secondly, spelling knowledge benefited mostly from ER, especially in languages which are difficult to spell such as French. Therefore, English spelling knowledge can be mainly developed due to its spelling simplicity in comparison with French. Apart from this, learners can also acquire meaning through reading but not to the same extent. Overall, spelling is the lexical aspect that mostly benefited from ER with even few exposures. Knowledge of meaning and prepositions seems to be obtained gradually at a similar lower level. Finally, lexical knowledge improvement is affected by the frequency of occurrence in the texts. However, when words are seen more than twenty times in a text, word knowledge will be increased.

Waring (2006) claims that ER or graded reading is a necessary part of any language program. In order to illustrate ER, he introduced two different types of learning: 1) learning to use language, and 2) studying about language. The former means to be able to use language fluently in communicative contexts without sticking to the language features and the latter means understanding how the language works and finding about its vocabulary, grammar, sound system, etc. He argues that the focus of ER and GR is on meaning; therefore, they are preferred over course books in language learning and teaching. Learners increase their vocabulary knowledge through more exposure to a large amount of texts. They learn new vocabulary and enrich the old ones, as Nation (1997) agreed upon as well. Consequently, this depth of vocabulary knowledge gives learners the confidence in speaking and writing.

A number of studies (Day \&Bamford, 1998; Nation, 1997) have shown proficiency gains through ER. Imrie (2007) started an investigation concerning the benefits of ER in promoting autonomy. The growth of learners' autonomy through using graded readers and the degree of success were discussed in his paper. Reading out of the classroom is usually considered one of the characteristics of ER which has clear and outstanding benefits. In this study, the more the students were exposed to graded readers out of the classroom, the better their reading speed was. As the students read self-selected books at their own proficiency level out of the classroom, they took responsibility for their own learning. This process of learning was continued wherever and whenever they wanted and it also made students independent learners. Independency, autonomy, or individualization were the terms used to define the way of working which learners are expected to do in ER program. Imrie also proposed that ER changed learners' study and reading habits. Graded readers were very successful in ER as a means of presenting learners' autonomy through selecting what they wanted to read; they were also suitable for learners' proficiency level at their favorite time and place out of the classroom. In fact, these factors all led to improved and successful autonomy.

Yamashita (2008) discussed the effects of this kind of reading on the development of different aspects of L2 proficiency and FL/SL ability. Some of these abilities may be improved and some may not. For the students included in this study, their English class was the target class, and the only reading they did during the program was ER. Yamashita also argued that this type of reading (ER) seems more likely to improve the acquisition of vocabulary, expressions and automaticity. This may be the cause of repetitive exposure to the reading materials and the target language. As 
development of general reading ability and lower-level linguistic ability were also examined in his study, the findings indicated an improvement in reading ability of participants. However, their linguistic ability did not change and stayed constant.

Lee and Hsu (2009) examined the impact of ER on less successful students' writing in a Taiwanese university. In the measurement of their writing, five subscales were included: content, vocabulary organization, mechanics and language use. The same numbers of writing assignments were done by all of the students in a writing class. The results indicated that reading has a strong and remarkable effect on writing and fluency. Having a longer duration was essential in having better results and this study confirmed that the longer the period of ER program, the better the writing development.

Benettayeb (2010) investigated the role of ER in vocabulary learning and teaching, automaticity, and reading fluency. She proposed that reading as a communicative and a learning tool was a basic skill which must be learnt by FL/SL learners. She also argued that among the numerous types of techniques for teaching vocabulary, ER is the best. Based on her study, the relationship between vocabulary and reading comprehension is evident. The findings indicated that without understanding the text vocabularies, text comprehension was impossible both in native and foreign languages. In other words, reading development is supported by vocabulary knowledge and vocabulary knowledge is increased through reading. Therefore, the more FL/SL learners read, the more the exposure to vocabulary items, and the more their reading fluency develops.

\section{MethodOLOGY}

\section{Participants}

The participants of the present study were 60 students (30 control group and 30 experimental group) studying EFL in an English institute. Their sex and age were not taken into account. They were selected from among the elementary, intermediate and advanced levels. All of the participants took both pre-test and post-test of Gardner' AMTB and Schmidt et al.'s MQ in Persian with a total number of 155 questions. They were assigned to three groups of 20 members each (20 elementary, 20 intermediate and 20 advanced participants) in which 10 of the participants were in the control group who continued their regular reading instruction and the other 10 participants were in the experimental group who did ER program during two semesters.

\section{Instruments}

For conducting the study and collecting data, the following instruments were used:

- Attitude/Motivation Test Battery (AMTB) and Schmidt's Motivation Questionnaire (SMQ): In order to collect data in the field of motivation as an important factor in language acquisition, these questionnaires with a total number of 155 questions (104 questions of the former and 51 questions of the latter in which 1 item was asked in four different ways) were administered to all elementary, intermediate and advanced levels to know about their motivation level.

- Pre-test and Post-test: Since the participants in the study might not have the same level of motivation for speaking, AMTB and SMQ pre-tests were administered to them to know about their prior motivation. After all participants did ER program, for measuring the level of their motivation for speaking AMTB and SMQ post-tests were given to all of them as well.

- Graded Readers (GR): The students were asked to use the graded readers which were available in the library of the institute.

- Library: The library of the institute had 120 graded readers for all levels; the books were classified into three parts according to the level of the books: 1) beginner and elementary, 2) lower-intermediate and intermediate, 3) upperintermediate and advanced. Students chose their books based on their levels and interest with their library cards.

Procedure

A total number of 60 students in an English institute were selected. Sex and age were not taken into account. To collect data about students' prior motivation, the AMTB and SMQ pre-tests were administered to all participants. As a treatment one session was held to introduce ER and the process of doing this kind of reading to the students. Then, from the following session students were asked to choose a graded reader from the institute's library based on their interest at their own level. The participants were supposed to read three books in a week (all classes were held 3 times a week). They were also asked to keep reading extensively following their own interest as an out of class activity. To make sure that all participants keep reading extensively, the teacher asked them to give a summary (oral or written) of what they had read. To have a serious reading program, the students were also told that the program is part of their English education and will affect their final scores. The period of ER practice lasted for 2 whole semesters (12 weeks). At the end of the instruction, the post-test of AMTB and SMQ were administered to the participants to be compared with data collected in pre-test.

\section{Results}

A set of test scores should satisfy four assumptions before being analyzed through parametric tests (Filed, 2009). These four assumptions are Independence, Interval data, normality and homogeneity of variances. The assumptions of independence and interval data do not have any statistical indices. No subject should participate in more than one group 
- independence - and the dependent variable(s) should be measured at least on an interval scale -interval data. However the assumptions of normality and homogeneity of variances should be probed empirically.

In order to test the assumption of normality, the ratio of Skewness and Kurtosis over their respective standard errors should be within the ranges of +/- 1.96 (Filed, 2009). As displayed in Table 1, the ratios of Skewness and Kurtosis over their associated standard errors are all with in the ranges of $+/-1.96$. Based on these results it can be concluded that the present data enjoy normality assumption.

TABLE 1.

NORMALITY TESTS

\begin{tabular}{|c|c|c|c|c|c|c|c|c|}
\hline & \multirow{2}{*}{\begin{tabular}{|l|}
$\mathrm{N}$ \\
Statistic \\
\end{tabular}} & \multirow{2}{*}{\begin{tabular}{|l} 
Mean \\
Statistic
\end{tabular}} & \multicolumn{2}{|l|}{ Skewness } & \multirow{2}{*}{$\begin{array}{l}\text { Normality of } \\
\text { Skewness }\end{array}$} & \multicolumn{2}{|l|}{ Kurtosis } & \multirow{2}{*}{$\begin{array}{l}\text { Normality } \\
\text { Of Kurtosis }\end{array}$} \\
\hline & & & Statistic & Std. Error & & Statistic & Std. Error & \\
\hline PRETEST & 60 & 635.2500 & -0.555 & 0.309 & -1.79 & 0.597 & 0.608 & 0.98 \\
\hline POSTTEST & 60 & 634.9333 & -0.476 & 0.309 & 1.54 & 0.896 & 0.608 & 1.47 \\
\hline
\end{tabular}

The assumption of homogeneity of variances will be covered when discussing the results of the independent $t$-test and two-way ANOVA below.

\section{Pretest}

An independent t-test was used to compare the experimental and control groups' mean scores on the pretest in order to prove that the two groups were homogenous in terms of their motivation for speaking before the administration of the treatment. The t-observe value of $1.27(\mathrm{P}=0.208>0.05)$ indicates that there were no significant differences between the experimental and control groups' mean scores on the pretest. This shows that the two groups were homogenous in terms of their motivation for speaking before the administration of the treatment.

TABLE 2.

INDEPENDENT T-TEST PRETEST OF SPEAKING MOTIVATION

\begin{tabular}{|c|c|c|c|c|c|c|c|c|c|}
\hline & \multicolumn{2}{|c|}{$\begin{array}{l}\text { Levene's Test for Equality } \\
\text { of Variances }\end{array}$} & \multicolumn{7}{|c|}{ t-test for Equality of Means } \\
\hline & \multirow[t]{2}{*}{$\mathrm{F}$} & \multirow[t]{2}{*}{ Sig. } & \multirow[t]{2}{*}{$\mathrm{T}$} & \multirow[t]{2}{*}{ df } & \multirow{2}{*}{$\begin{array}{l}\text { Sig. } \\
\text { (2-tailed) }\end{array}$} & \multirow{2}{*}{$\begin{array}{l}\text { Mean } \\
\text { Difference }\end{array}$} & \multirow{2}{*}{$\begin{array}{l}\text { Std. Error } \\
\text { Difference }\end{array}$} & \multicolumn{2}{|c|}{$\begin{array}{l}95 \% \text { Confidence Interval } \\
\text { of the Difference }\end{array}$} \\
\hline & & & & & & & & Lower & Upper \\
\hline Equal variances assumed & 1.02 & 0.317 & 1.27 & 58 & 0.208 & 11.10 & 8.71 & -6.34 & 28.54 \\
\hline Equal variances not assumed & & & 1.27 & 54.54 & 0.208 & 11.10 & 8.71 & -6.36 & 28.56 \\
\hline
\end{tabular}

As displayed in Table 3, the mean scores for the experimental and control groups on the pretest of speaking motivation are 629.70 and 640.80 , respectively.

TABLE 3.

DESCRIPTIVE STATISTICS PRETEST OF SPEAKING MOTIVATION

\begin{tabular}{|l|l|l|l|l|}
\hline GROUP & $\mathrm{N}$ & Mean & Std. Deviation & Std. Error Mean \\
\hline CONTROL & 30 & 640.8000 & 29.19424 & 5.33011 \\
\hline EXPERIMENTAL & 30 & 629.7000 & 37.76255 & 6.89447 \\
\hline
\end{tabular}

The assumption of homogeneity of variances is met. As displayed in Table 2, the Levene's F of $1.02(\mathrm{P}=0.31>0.05)$ is not significant. That is why the first rows of Table 2, i.e. "Equal variances assumed" is reported.

\section{Research Questions}

1) Is there any improvement in FL learners' motivation for speaking following an ER program?

2) Are there any significant differences among the effect of ER on elementary, intermediate and advanced learners' motivation for speaking?

A two-way ANOVA was run to investigate the effect of the proficiency level (advanced, intermediate and elementary) and grouping variable (experimental and control) on the posttest. The F-value for the comparison of the two groups probed the first research question while the F-value for the effect of the proficiency levels tapped on the second research question.

As displayed in Table 4, the Levene's F of $1.47(\mathrm{P}=0.21>0.05)$ is not significant. Thus it can be concluded that the two-way ANOVA design does not violate the assumption of homogeneity of variances.

TABLE 4.

LEVENE'S TEST OF HOMOGENEITY OF VARIANCES FOR TWO-WAY ANOVA

\begin{tabular}{|l|l|l|l|}
\hline $\mathrm{F}$ & $\mathrm{df} 1$ & $\mathrm{df} 2$ & Sig. \\
\hline 1.478 & 5 & 54 & 0.212 \\
\hline
\end{tabular}

The F-observed value for the effect of the treatment factor was not significant $(\mathrm{F}=3.45, \mathrm{P}=0.069>0.05)($ Table 5). Based on these results it can be concluded that there is no significant difference between the mean scores of the experimental and control groups on the posttest of speaking motivation. Thus the first null-hypothesis as there is not any improvement in FL learners' motivation for speaking following an ER program is supported. 
TABLE 5.

TWO-WAY ANOVA RESULTS FOR POST-TEST

\begin{tabular}{|l|l|l|l|l|l|l|}
\hline Source & Type III Sum of Squares & Df & Mean Square & F \\
\hline GROUP & 2208.267 & 1 & 2208.267 & 3.454 & \\
\hline PROFICIENCY & 869.633 & 2 & 434.817 & 0.069 \\
\hline GROUP * PROFICIENCY & 17337.233 & 2 & 8668.617 & 0.680 \\
\hline Error & 34524.600 & 54 & 639.344 & 13.559 & \\
\hline Total & 24243360.00 & 60 & & 0.000 \\
\hline
\end{tabular}

As displayed in Table 6 the mean scores for the experimental and control groups on the posttest of speaking motivation are 628.86 and 641 , respectively.

TABLE 6.

DESCRIPTIVE STATISTICS POSTTEST OF SPEAKING Motivation By Groups

\begin{tabular}{|l|l|l|l|l|}
\hline \multirow{2}{*}{ GROUP } & \multirow{2}{*}{ Mean } & \multirow{2}{*}{ Std. Error } & \multicolumn{3}{|l|}{ 95\% Confidence Interval } \\
\cline { 4 - 6 } & & & Lower Bound & Upper Bound \\
\hline CONTROL & 641.000 & 4.616 & 631.745 & 650.255 \\
\hline EXPERIMENTAL & 628.867 & 4.616 & 619.611 & 638.122 \\
\hline
\end{tabular}

The F-observed value for the effect of the proficiency levels was not significant $(\mathrm{F}=0.68, \mathrm{P}=0.51>0.05)$ (Table 5). Based on these results, it can be concluded that the proficiency levels do not have any significant effect on the performance of the students on the posttest of speaking motivation. Thus the second null-hypothesis as there are not any significant differences among the effect of ER on elementary, intermediate and advanced learners' motivation for speaking is also supported.

As displayed in Table 7 the mean scores for the advanced, intermediate and elementary students on the posttest of speaking motivation are $637.55,629.55$ and 637.70 , respectively.

TABLE 7.

DESCRIPTIVE Statistics PostTest OF SPEAKING Motivation By PROFICIENCY LEVELS

\begin{tabular}{|l|l|l|l|l|}
\hline \multirow{2}{*}{ PROFICIENCY } & \multirow{2}{*}{ Mean } & \multirow{2}{*}{ Std. Error } & \multicolumn{2}{|l|}{ 95\% Confidence Interval } \\
\cline { 3 - 5 } & & & Lower Bound & Upper Bound \\
\hline ADVANCED & 637.550 & 5.654 & 626.215 & 648.885 \\
\hline INTERMEDIATE & 629.550 & 5.654 & 618.215 & 640.885 \\
\hline ELEMNTARY & 637.700 & 5.654 & 626.365 & 649.035 \\
\hline
\end{tabular}

As it is the concern of the present study, there is a significant interaction between the grouping variables and the proficiency levels $(\mathrm{F}=13.55, \mathrm{P}=0.000<0.05)$ (Table 5). As displayed in Table 8 and Graph 1 , at elementary and intermediate levels, the experimental group performed better than the control group. However at advanced level the reverse happened. The control group outperformed the experimental group.

TABLE 8

DESCRIPTIVE STATISTICS INTERACTION BETWEEN GROUPING VARIABLE AND PROFICIENCY LEVELS

\begin{tabular}{|c|c|c|c|c|c|}
\hline \multirow{2}{*}{ GROUP } & \multirow{2}{*}{ PROFICIENCY } & \multirow{2}{*}{ Mean } & \multirow{2}{*}{ Std. Error } & \multicolumn{2}{|c|}{$95 \%$ Confidence Interval } \\
\hline & & & & Lower Bound & Upper Bound \\
\hline \multirow{3}{*}{ CONTROL } & ADVANCED & 667.600 & 7.996 & 651.569 & 683.631 \\
\hline & INTERMEDIATE & 622.200 & 7.996 & 606.169 & 638.231 \\
\hline & ELEMNTARY & 633.200 & 7.996 & 617.169 & 649.231 \\
\hline \multirow{3}{*}{ EXPERIMENTAL } & ADVANCED & 607.500 & 7.996 & 591.469 & 623.531 \\
\hline & INTERMEDIATE & 636.900 & 7.996 & 620.869 & 652.931 \\
\hline & ELEMNTARY & 642.200 & 7.996 & 626.169 & 658.231 \\
\hline
\end{tabular}

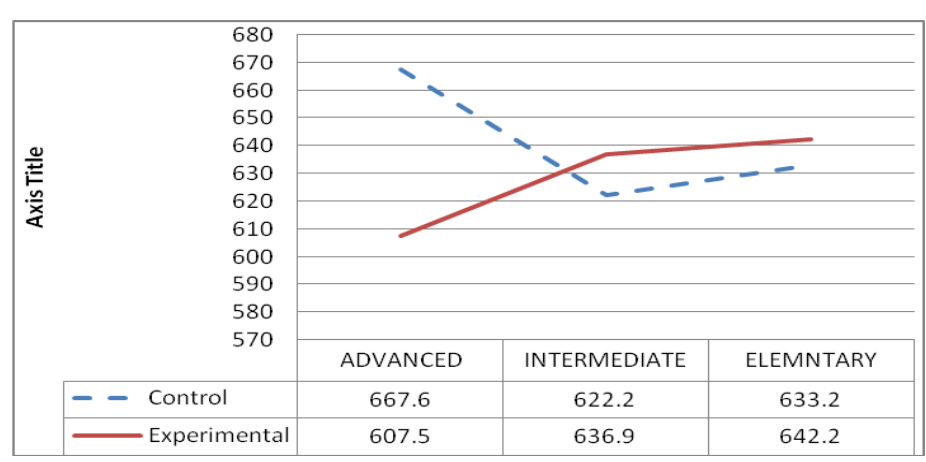

Graph 1. Interaction between Grouping Variable and Proficiency Levels

\section{DISCUSSION}


The present study examined the effect of ER on Iranian EFL learners' motivation for speaking. According to the results ER was not effective for Iranian L2 learners who lack the necessary motivation for speaking. In this section, the unexpected results of the present study are compared with the results of the studies conducted previously. Based on the results, it can be concluded that there is no significant difference between the mean scores of the experimental and control groups on the posttest of speaking motivation. Thus the first null-hypothesis as there is not any improvement in FL learners' motivation for speaking following an ER program is supported. This means after doing ER for L2 learners of an institute in Iran during 12 weeks, their motivation for speaking did not increase. The finding of this study is in agreement with the study by Mori (2002), who hypothesized that reading and motivation to communicate may be different and unrelated. The finding of his study showed that when students do not have enough contact with English language and culture, they do not have the necessary desire to read English texts. He claimed that the more the L2 learners contact with the target language, the more they become motivated to read in L2. However, according to his study, and the amount of their reading, L2 learners' motivation to read did not affect their motivation to communicate.

The investigations that have been done by Day and Bamford (1998), Powell (2005), and Waring (2006) are in contrast to the findings the present study. The findings of the investigations by Day and Bamford (1998), and Powell (2005) showed that ER is the basis for listening, speaking and writing activities. In addition, Waring (2006) declared that being exposure to vocabularies and the large number of texts in ER or GR, high vocabulary knowledge makes learners confident enough in speaking and writing. However the present study showed that ER had no significant effect on L2 learners' speaking.

Although many studies (Asraf\& Ahmad, 2003; Bell, 2001; Fender, 2008; Hitosugi\& Day, 2004; Nishino 2007; Powell, 2005; Shen, 2008) have done ER program on L2 learners of different levels, the findings of most of them showed that ER affects students who have low L2 proficiency level. However, the results of the present study revealed that the F-observed value for the effect of the proficiency levels was not significant. Based on the results of the present study, it can be concluded that the proficiency levels do not have any significant effect on the performance of the students on the posttest of speaking motivation. Thus the second null-hypothesis as there are no significant differences among the effect of ER on elementary, intermediate and advanced learners' motivation for speaking is supported as well.

Doing ER in the present study lasted for twelve weeks but the post tests showed ER did not affect the participants' motivation for speaking. This may be due to insufficient time for doing ER. As Asraf and Ahmad (2003) and Hitosugi and Day (2004) claimed, to gain remarkable results in language learning, L2 learners needed a longitudinal reading program. In this study, the period of ER program was 12 weeks which is too short to achieve the favorite results.

\section{CONCLUSION}

Based on the results of the present study, the learners' speaking motivation is not related to reading extensively. Although the participants read three books in a week during two semesters, their motivation did not change. This may be due to the limited time they had for experiencing ER as Asraf and Ahmad (2003) and Hitosugi and Day (2004) agreed upon. In addition, in Iran L2 learners do not have the necessary desire to read English texts such as newspapers, magazines, books, etc. This may be due to the lack of contact with English language and culture. Therefore, lack of improvement in participants' speaking motivation in this study can be due to the fact that they did not have enough contact with English and this leads them to demotivation in reading. Consequently, the less they read in English, the less they improve in speaking and language knowledge.

It was also found that ER is not related to the learners' proficiency level. Students' motivation for speaking in all three levels (elementary, intermediate and advanced) was not impressed by reading extensively. Despite the fact that ER develops FL learners' L2 vocabulary, grammar, spelling, reading speed, reading comprehension and reading motivation, it did not improve the participants' motivation for speaking across the proficiency levels.

ER can be used in schools and universities' curriculums for longer periods of time. Teachers and university instructors can use ER in their classes for FL learners to motivate them to read. This may help FL learners to improve their knowledge of vocabulary and grammar. Further research should be conducted in the area of extensive reading, motivation, and speaking or communicating in foreign languages. Future studies can investigate whether allocation of longer period of time for ER program affect EFL learners' speaking motivation, and whether learners' gender affect their motivation to read extensively.

\section{REFERENCES}

[1] Asraf, R.M. \& Ahmad, I. S. (2003). Promoting English language development and the reading habit among students in rural schools through guided extensive reading program. Reading in Foreign Language, 15(2), 94-102.

[2] Bell, T. (2001). Extensive reading: speed and comprehension. The Reading Matrix, 1(1), 1-13. Retrieved September 17, 2007, from http://www.readingmatrix.com/archives.html.

[3] Benettayeb, A. (2010). Extensive reading and vocabulary teaching. Revue Academique des Etudes Sociales et Humaines, 3, 2030.

[4] Brewster, C. \& Fager, J. (2000). Increasing student engagement and motivation: From time-on-task to homework. NW Regional Educational Laboratory. Retrieved June 19, 2002, from http//www.nwrel.org/request/oct00/textonly.html. 
[5] Chalak, A. \& Kassaian, Z. (2010). Motivation and attitude of Iranian undergraduate EFL students towards learning English. GEMA Online Journal of Language Studies, 10(2), 37-56.

[6] Day, R. R. \& Bamford, J. (1998). Extensive reading in the second language classroom. Cambridge: Cambridge University Press.

[7] Fender, M. (2008). Spelling knowledge and reading development: Insights from Arab ESL learners. Reading in a Foreign Language, 20(1), 19-42.

[8] Field, A. (2009). Discovering Statistics Using SPSS.3rd ed. SAGE. London.

[9] Fritze, J. \& Rowan, K. (2005). Access to books and a quiet comfortable place to read: A practical guide to establishing a free voluntary reading program. IJFLT, 1(4), 27-29.

[10] Hashimoto, Y. (2002). Motivation and willingness to communicate as predictors of reported L2 use: The Japanese ESL context. Second Language Studies, 20(2), 29-70.

[11] Hitosugi, C. I. \& Day, R. R. (2004). Extensive reading in Japanese. Reading in a Foreign Language, 16(1), 20-39.

[12] Imrie, A. (2007). Autonomy across the English curriculum through extensive reading. Independent Learning Association. 1- 8.

[13] Iwahori, Y. (2008). Developing reading fluency: A study of extensive reading in EFL. Reading in a Foreign Language, 20(1), 70-91.

[14] Jarrell, D. S. (2003). Extensive reading for weak readers. Nagoya Joshi Daigaku Kiyou, 49, 199-205. Retrieved from http://libweb.nagoya-wu.ac.jp/kiyo/kiyo49/kj4917.pdf.

[15] Judge, P. B. (2011). Driven to read: Enthusiastic readers in a Japanese high school's extensive reading program. Reading in a Foreign Language, 23(2), 161-186.

[16] Kato, F., Yasumoto, S., \& Van Aacken, S. (2007). A comparative study: Motivation of learners of Japanese. Electronic Journal of Foreign Language Teaching, 4(1), 41-57.

[17] Kit U, C. (2009). Reading and second language acquisition. HKBU Papers in Applied Language Studies, 13.

[18] Koch, T. (2006). Extensive reading: A simple technique with outstanding results. $19^{\text {th }}$ Annual EA Education Conference.

[19] Lee S. Y. \& Hsu, Y. Y. (2009). Determining the crucial characteristics of extensive reading program: The impact of extensive reading on EFL writing. IJFLT, 12-20.

[20] Leung, C. Y. (2002). Extensive reading language learning: A diary study of a beginning learner of Japanese. Reading in a Foreign Language, 14(1), 66-81.

[21] Mason, B. \& Krashen, S. D. (1997). Extensive reading in English as a foreign language. System, 25, 91-102.

[22] Matsuoka, R. \& Evans, D. R. (2005). Willingness to communicate in the second language. J Nurs Studies NCNJ, 4(1), 3-12.

[23] Mori, S. (2002). Redefining motivation to read in a foreign language. Reading in Foreign Language, 14(2), 91-110.

[24] Moriam, Q. M. (2008). A study on motivation and strategy use of Bangladeshi university students to learn spoken English. Journal of International Development and Cooperation, 14(2), 51-66.

[25] Nation, P. (1997). The language learning benefits of Extensive Reading. The Language Teacher, 21(5), 3-16. Retrieved March 24, 2004, from http://langue.hyper.chubu.ac.up/jalt/pub/tlt/97/may/benefits.html.

[26] Nishino, T. (2007). Beginning to read extensively: A case study with Mako and Fumi. Reading in Foreign Language, 19(2).

[27] Obeidat, M. M. (2005). Attitudes and motivation in second language learning. Journal of Faculty of Education, 18(22), 1-17.

[28] Pallant, J. (2005). SPSS Survival Manual. Allen \& Unwin. NSW. Australia.

[29] Pigada, M. \& Schmitt, N. (2006). Vocabulary acquisition from extensive reading: A case study. Reading in a Foreign Language, 18(1).

[30] Powell, S. (2005). Extensive reading and its role in Japanese high schools. The Reading Matrix, 5(2), 28-42.

[31] Richards, J. C. \& Schmidt, R. (2002). Longman dictionary of language teaching and applied linguistics, $3^{\text {rd }}$ Ed. Pearson Education. London.

[32] Rosszell, R. (2006). The role of extensive reading in second language vocabulary acquisition. In K. Bradford-Watts, C. Ikeguchi, \& M. Swanson (Eds.), JALT2005 Conference Proceeding. Tokyo: JALT, 394-407.

[33] Shen, M. Y. (2008). EFL learners' responses to extensive reading: Survey and pedagogical applications. The Reading Matrix, $8(2)$.

[34] Sheu, S. P. H. (2004). The effect of extensive reading on learners' reading ability development. Journal of National Taipei Teachers College, 17(2), 213-228.

[35] Taguchi, E., Takayasu-Maass, M., \& Gorsuch, G. J. (2004). Developing reading fluency in EFL: How assisted repeated reading and extensive reading affect fluency development. Reading in Foreign Language, 16(2).

[36] Takase, A. (2007). Japanese high school students' motivation for extensive L2 reading. Reading in Foreign Language, 19(1).

[37] Tanaka, H. \& Stapleton, P. (2007). Increasing reading input in Japanese high school EFL classrooms: An empirical study exploring the efficacy of extensive reading. The Reading Matrix, 7(1), 115-131.

[38] Waring, R. (1997). Graded and Extensive Reading-Questions and Answers. The Language Teacher, 21(5), 9-12. Available:http://jalt-publications.org/tlt/files/97/may/waring.html.

[39] Yamashita, J. (2008). Extensive reading and the development of different aspects of language proficiency. System, 36, 661-672.

[40] Yamashita, J. (2004). Reading attitudes in L1\& L2, and their influence on L2 extensive reading. Reading in Foreign Language, 16(1), 1- 19.

[41] Yashima, T. (2002). Willingness to communicate in a second language: The Japanese EFL context. The Modern Language Journal, 86(2), 54-66.

[42] Zubairi, A. M. \& Sarudin, I. H. (2009). Motivation to learn a foreign language in Malaysia. GEMA Online Journal of Language Studies, 9(2). 


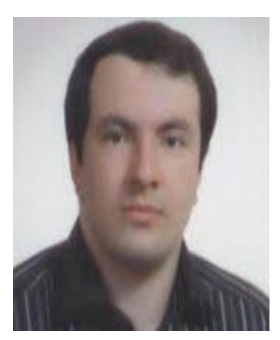

Ramin Rahmany is a PhD holder in TEFL from the University of Tehran. Born in Takestan in 1978, he has been teaching MA and BA courses in universities in Takestan and Tehran. His research interests include language learning and sentence processing. $\mathrm{He}$ is currently doing an MA degree in Linguistics at the University of Tehran.

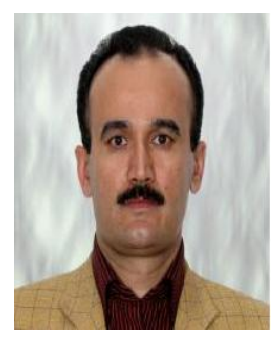

Abbas Ali Zarei is a Ph.D holder in Teaching English as a Foreign Language. He was born in Qazvin, Iran in 1972. In 1994, he got his BA in 'teaching English as a foreign language' from the University for Teacher Education in Tehran. He got his MA and PhD, both in 'TEFL' from Tehran University and Isfahan University in Iran in 1996 and 2002, respectively. He is currently a member of academic staff at Imam Khomeini International University (IKIU) in Qazvin. He has 16 years of teaching experience. His main area of interest is vocabulary learning and the factors influencing it. He has written and published 14 books and translated four others. He has also had numerous articles published, mostly in the area of vocabulary learning.

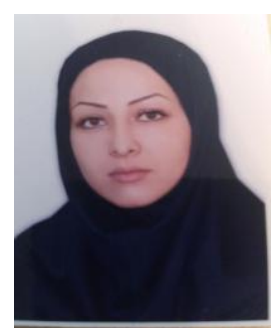

Sohaila Gilak is an MA holder in TEFL from Azad University of Takestan. She was born in Zanjan, Iran in 1981. She got her BA in 'English Translation' from the University of Zanjan, and worked as an interpreter in Croatian, Pakistani and German Embassies in Tehran. She has 9 years of teaching experience and her primary research interests include reading, motivation and second language learning. 